\title{
Геология «Предуралья». Монография
}

\section{Ю.Г. Пактовский}

Пермский государственный национальный исследовательский университет, 614990, Пермь, ул. Букирева, 15. E-mail: mineral@psu.ru

(Статья поступила в редакцию 19 августа 2017 г.)

Рецензируется новая монография коллектива авторов, посвященная различным аспектам геологического строения территории заказника «Предуралье», где находится учебно-научная база Пермского государственного национального исследовательского университета. В книге приводится оригинальный материал по стратиграфии, литологии, геохимии и комплексным геофизическим исследованиям на территории заказника.

Ключевые слова: региональная геология, геохимия, геофизика, «Предуралье», монография, рецензия.

DOI: 10.17072/psu.geol.16.3.298

Издательский центр Пермского государственного национального исследовательского университета выпустил в свет монографию «Геология "Предуралья"» с подзаголовком

«Геология, геохимия и геофизика учебнонаучной базы "Предуралье"». Авторский коллектив включает двадцать исследователей разной специализации, тринадцать из которых входят в состав геологического факультета Пермского университета. Книга предназначена для оказания помощи в профессиональной подготовке студентов геологического факультета Пермского университета, но заинтересует всех занимающихся геологией Предуралья.

Она состоит из трех частей. В первой части охарактеризованы различные аспекты региональной геологии УНБ «Предуралье». В стратиграфическом описании подробно рассмотрены органогенные постройки сылвенской свиты кунгурского яруса приуральского отдела пермской системы, показано их принципиальное отличие от «настоящих рифов»; приведены данные по организмам-рифостроителям сылвенских «рифов», в первую очередь тубифитам - проблематичным организмам, которым мы и обязаны образованию таких памятников природы, как Камайские Зубцы, Камень Ермак, Камень Межевой и др. Особое внимание уделено типовым разрезам на территории УНБ «Предуралье». Ю.Г. Пономаревой описана «дивьинская» свита в разрезах Межевой лог и Камайский лог в составе саранинского горизонта кунгурского яруса. Палеогеографическая реконструкция показывает фациальную неоднородность морского шельфа кунгурского века на территории нынешнего заказника и учебно-научной базы. Типовые разрезы иллюстрированы фотографиями полевых материалов; для каждого из них составлены стратиграфическая колонка и геологическое описание; приведены также палеонтологические таблицы для разреза Камайский лог. Завершает первую часть книги палеореконструкция обстановки осадконакопления эпохи плиоцена, выполненная И.Я. Илалтдиновым. Анализ морфологии галечного материала свидетельствует о характерном для литоральной зоны смешении признаков наземного и морского режимов. На основании литологопетрографического анализа галечников четвертой террасы р. Сылвы делается вывод о влиянии ингрессии Каспийского 
моря, шедшей по долинам крупных рек в конце плиоцена.

Вторая часть монографии логически примыкает к первой и посвящена геохимической характеристике органического вещества и битумоидов пород «дивьинской» свиты разреза Камайский Лог. Комплекс аналитических методов позволил установить исходное органическое вещество для нефтематеринских пород свиты, не успевших вступить в главную фазу нефтеобразования. Кроме того, как это часто бывает, детальное исследование выявило ряд вопросов, требующих дальнейшего теоретического осмысления. Одним из них является вопрос о степени стойкости органического вещества в условиях гипергенеза. Интерпретацию полученных результатов авторы второй части монографии обещают представить в недалеком будущем. Итогом данной работы стал геохимический разрез дивьинской свиты разреза Камайский Лог.

Завершающая монографию третья часть посвящена геофизическим исследованиям, преследующим несколько целей: учебную, научную и прикладную. Геодинамический (геофизический) полигон «Предуралье» имеет свою историю и солидную материальную базу (Вестник, 2000). С 1989 г. проводятся исследования территории различными геофизическими методами: гравиметрическим, магниторазведки, электроразведки и сейсморазведки, а также методами и каротажами ГИС. Своеобразие геодинамического полигона УНБ «Предуралье» в том, что здесь имеется возможность проведения полного комплекса геофизического изучения с постоянным и непрерывным мониторингом территории в течение многих лет. Комплекс геофизических методов позволяет отслеживать уровень грунтовых вод и его изменение, распространение и динамику карстовых процессов, неоднородности строения толщ, техногенное влияние на природную обстановку и т.д. Каждому из геофизических методов посвящена отдельная глава.

Выпуск монографии приурочен к юбилею заказника «Предуралье», которому 31 августа 2017 г. исполнилось 75 лет.

\section{Библиографический список}

Вестник Пермского университета. Заказник «Предуралье». 2000. Вып. 3. 328 с.

Геология «Предуралья» (геология, геохимия и геофизика УНБ «Предуралье»): монография / Г.Ю. Пономарева, Т.В. Филимонова, О.Л. Коссовская и др.; отв. ред. Г.Ю. Пономарева, И.Ю. Герасимова, И.С. Хопта; Перм. гос. нац. исслед. ун-т. Пермь, 2017. 216 с.

\section{Geology of the «Preduralye». Monograph}

\section{Y.G. Paktovsky}

\section{Perm State University. 15 Bukirev Str., Perm 614990, Russia}

E-mail: mineral@psu.ru

The monograph is devoted to various aspects of the geological structure of the territory «Preduralie» (the reserve and the eponymous educational and scientific base of the Perm State University). The book contains original material on stratigraphy, lithology, geochemistry and geophysical studies on the educational and scientific base «Preduralye».

Key words: regional geology; geochemistry; geophysics; "Preduralye»; monograph; review.

\section{References}

Zakaznik «Preduralye» 2000. [The Reserve "Preduralye]." Vestnik Permskogo universiteta. Nauchnyy zhurnal. V. 3, p. 328. (in Russian)

Ponomareva G.Yu., Gerasimova I.Yu., Hopta I.S. 2017. Geologiya «Preduralya» (geologiya, geokhimiya i geofizika UNB «Preduralye»), [Geology of the «Preduralye» (geology, geochemistry and geophysics of the educational and scientific base «Preduralye»)]. Perm, Perm State University, p. 216. (in Russian) 